Jurnal Keperawatan Padjadjaran

ISSN 2338-5324 (print)

ISSN 2442-7276 (online)

Online di http://jkp.fkep.unpad.ac.id

DOI : $10.24198 / \mathrm{jkp}$

\title{
Measuring Work Fatigue on Nurses: A Comparison between Indonesian Version of Fatigue Assessment Scale (FAS) and Japanese Industrial Fatigue Ressearch Commite (JIFRC) Fatigue Questionnaire
}

\author{
Iwan Muhamad Ramdan \\ Faculty of Public Health Universitas Mulawarman, Samarinda, Indonesia \\ Correspondingemail: iwanmuhamadramdan@gmail.com
}

Submitted: 04-12-2019 Accepted: 16-07-2019 Published: 01-08-2019

\begin{abstract}
A Nursing is one type of jobs that is at risk of experiencing fatigue because its workload is quite high. Fatigue Assessment Scale (FAS) and Japanese Industrial Fatigue Research Committee (JIFRC) fatigue questionnaire are two instruments that are often used to measure work fatigue in various types of work because the ease of use. This study aims to test and compare the validity and reliability of the Indonesian version of FAS and JIFRC among nurses in one governmental hospital in East Kalimantan Indonesia. The study was conducted on 170 nurses in one of the Class A Referral Government Hospitals in East Kalimantan. Determination of the study sample using stratification simple random sampling method, the FAS questionnaire obtained from Zuraida \& Chie, the JIFRC questionnaire was taken from Tarwaka, the Validity and Reliability test using Pearson Product Moment and Cronbach's alpha. The JIFRC in Indonesian version has a satisfactory psychometric property with adequate validity and reliability to assess work fatigue in nursing profession. The best Cronbach alpha (0.921) will be obtained if item number 3 and 16 are corrected for the editorial/sentence arrangement
\end{abstract}

Keywords: Fatigue Assessment Scale (FAS), Japan Industrial Fatigue Research Committee (JIFRC), nurses, validity and reliability, work fatigue. 
Iwan Muhamad Ramdan: Measuring Work Fatigue on Nurses: A Comparison between Indonesian Version

\section{Introduction}

Work fatigue is still an occupational health problem that needs attention from health and safety managers because it can have a detrimental impact on individuals and organizations. In general, work fatigue is a physical and psychological phenomenon that is defined as a condition of weakness, dislike and reluctance to continue current activities, not interested in doing further work, a decrease in alertness, a decrease in physical and emotional capacity, and a decreased ability to do certain jobs (Thiffault \& Bergeron, 2003). Fatigue experienced is basically a cumulative process and is indicated by a decrease in the ability to carry out tasks and a decrease in attention to stimuli from the environment. People who experience work fatigue also generally experience changes in motivation to complete their work (De Vries, Michielsen, \& Van Heck, 2003).

Work fatigue has an impact on biological balance, psychological and cognitive processes. At the individual level, work fatigue has a detrimental effect because it can reduce concentration and thinking power, decrease physical capacity, excessive dependence on others, become easily forgotten, have difficulty perceiving and respond to dangerous situations, communication difficulties and a decrease in the quality of personal life. While from the aspect of the organization, work fatigue experienced by its personnel will have an impact on decreasing the quality of service to consumers, increasing the number of turnover and decreasing work productivity (Bao \& Taliaferro, 2015; Blouin et al, 2016; Drake $\&$ Steege, 2016; Graves \& Simmons, 2009).

Nursing is one type of profession that is at risk of experiencing fatigue. This is because the main workload factor is high, as well as additional workloads such as having to operate a variety of high-tech medical and care equipment, must be responsible for the diagnosis and monitoring of patients with complications and emergency problems. The roles and responsibilities carried out by nurses on work, family and social life have caused nurses too often experience work fatigue as an accumulation of sleep disorders, lack of rest periods, physical and psychological stress and emotional changes.
(Barker \& Nussbaum, 2011; Bjorvatn et al, 2012; Korompeli et al, 2013; Samaha et al, 2007).

From the aspect of social relations, work fatigue that is not addressed will have an impact, among others, the deterioration of the relationship between nurse-patient, nurse-family, and other nurses. While from the aspect of work, work fatigue experienced by nurses can cause an increase in errors in nursing care, errors in carrying out doctor's advice, wrong decision making, and errors in monitoring and observing patients. All the effects of work fatigue will ultimately reduce the quality of service and patient safety (Carney, 2013; Drake \& Steege, 2016; Graves \& Simmons, 2009; Rahman et al, 2017; Scott et al, 2014; Steege et al, 2017).

According to Akerstedt \& Gillberg (1990), work fatigue can be measured subjectively and objectively, but there is no standard measuring tool to measure work fatigue. Some commonly used measuring instruments include subjective measurements based on questionnaires, psychomotor tests based on reaction time and concentration, measurement of ocular parameters and physiological measurements (Sibsambhu, Mayank, \& Aurobinda, 2010). Questionnaire-based subjective fatigue measurement is a measuring instrument that is quite widely used for reasons of practicality and measurement results can be obtained quickly. For the purposes of measuring work fatigue, there are a number of commonly used questionnaires including The brief fatigue inventory (BFI), Fatigue severity scale (FSS), Global vigor and affect (GVA), May and Kline adjective checklist, Pearson-Byars fatigue feeling checklist, Rhoten fatigue scale, Schedule of fatigue and anergia, Checklist individual strength (CIS), Fatigue assessment instrument (FAI), Fatigue impact scale (FIS), Fatigue rating scale (FRS), Fatigue assesment scale (FAS), Fatigue questionnaire, Fatigue severity inventory, Fatigue symptom inventory (FSI), Fisk fatigue severity score, Lee fatigue scale (LFS), Piper fatigue scale (PFS) and visual analogue scale for fatigue (Dittner, Wessely, \& Brown, 2004), and fatigue scale from Japanese industrial fatigue research commite (JIFRC) (Saito, 1999). 
Iwan Muhamad Ramdan: Measuring Work Fatigue on Nurses: A Comparison between Indonesian Version

Of the various fatigue scales, FAS and JIFRC are two questionnaires that are often used by researchers to measure work fatigue in various types of work and conditions. In accordance with the conclusion of Hendriks et al. (2018), FAS is a questionnaire that is often used to measure fatigue in various conditions and diseases (26 different condition and disease) in 19 countries and 12 languages. Meanwhile, JIFRC is a fatigue scale with a wide use and has been used to examine work fatigue in various jobs (Sunarno et al, 2017; Susihono et al., 2016; Konisi et al, 1991).

Fatigue Assessment Scale (FAS) is a work fatigue questionnaire developed by Michielsen et al. (2004), that contains 10 items of questions to reveal subjective work fatigue in the form of reflection of physical and mental work fatigue and its implications for motivation in carrying out activities. The FAS questionnaire was stated to have high reliability for measuring fatigue among workers (De Vries, Van der Steeg, \& Roukema, 2010). Whereas JIFRC fatigue scale is a work fatigue questionnaire compiled by the Japan industrial fatigue research committee (Saito, 1999; Sudo \& Ohtsuka, 2002). This questionnaire consists of 30 items of questions, generally divided into three parts (fatigue assessment related to weakening physical activity, fatigue associated with weakening motivation and fatigue associated with physical complaints) (Adiatmika, 2009; Susihono et al., 2016). FAS and JIFRC are quite widely used to assess work fatigue in various types of work because of practicality, do not need special skills to apply it, and respondents do not need much time to fill it, however scientific evidence that shows both of these measures is valid and reliable to assess work fatigue among nurses still in Indonesia still limited.

The quality of research is not only determined by the researcher's accuracy and research results, but also by the quality of the questionnaire used. In quantitative research, the quality of the measuring instrument used is achieved through measuring the validity and reliability of the questionnaire (Heale \& Twycross, 2015). Validity is to measure what is intended to be measured, reliability concerns the extent to which a measurement of a phenomenon provides stable and consist result (Taherdoost, 2016). This study aims to test the validity and reliability of the Indonesian version of FAS and JIFRC fatigue scale on nurses.

\section{Method}

\section{Research methods and samples}

The cross-sectional study was conducted on 170 samples of nurses in one of the Class A Referral Governmental Hospitals in East Kalimantan from May to July 2018. Determination of the sample study was carried out by stratificatied simple random sampling, taken from all private hospitalization rooms (Sakura and Teratai), public inpatient installations (Edelwise, Anggrek, Cempaka, Melati, Mawar, Cempaka, Aster, Flamboyan, Bougenvile, Seruni, Angsoka and Dahlia) and emergency room (ER).

\section{Instruments}

The Indonesian edition of the FAS questionnaire was taken from Zuraida \& Chie (2014), This questionnaire contains 10 questions to reveal the general feeling of work fatigue in the past year. The Indonesian edition of FAS uses five Likert scales with answer options consisting of: (1) never, (2) sometimes, (3) being felt regularly, (4) often experienced, (5) always experienced. The item questions in FAS consist of 1) I am bothered by fatigue, 2) I get tired very quickly, 3) I don't do much during the day, 4) I have enough energy for everyday life, 5) Physically I feel exhausted, 6) I have problems to start things, 7) I have problems to think clearly, 8) I feel no desire to do anything, 9) Mentally I feel exhausted, 10) When I am doing something I can concentrate quite well. Total scores obtained by summing all scores per item, then categorized into 2 (scores 1-30 = "low" work fatigue) and (score 31-60 = "high" work fatigue)

The Indonesian edition of the JIFRC questionnaire was taken from Tarwaka (2010), This questionnaire consists of 30 question items. In general, this questionnaire consisted of 3 parts, the first ten questions revealed "drowsiness and dullness", the second ten questions revealed "difficulty in concentration" and the third ten questions reveal "projection of physical disintegration", 
same as the FAS questionnaire, in this study the Indonesian version of IFRC questionnaire used five Likert scales with the answer options consisting of: (1) never, (2) sometimes, (3) being felt regularly, (4) often experienced, (5) always experienced. Total scores obtained by summing all scores per item, then categorized into 4: 1) scores 30-52="low" work fatigue; 2) scores $53-75=$ "medium" work fatigue; 3 ) scores 76-98="high" work fatigue; 4) scores 99-120="very high" work fatigue.

\section{Statistical Analyses}

Data were analyzed by the Statistical Package for the Social Sciences (SPSS ver. 21, Chicago, IL, USA), in order to describe mean, standard deviation (SD) and percentage frequency. The minimum, maximum and variance were also reported for each item of the questionnaire.

\section{Validity and Reliability}

Pearson Product Moment Correlation was used to evaluate the construct validity of each item to the total score. FAS and JIFRC test correlations were considered as 'good to excellent' when $r \geq 0.75$, as 'good' when $r$ ranged between 0.5 and 0.7 , as 'fair' when $r$ ranged between 0.25 and 0.50 , and as 'little or no relationship' when $\mathrm{r}$ was less than 0.25 (Kline, 2000; Portney \& Watkins, 2009).

Cronbach's alpha scores were used to assess the internal consistency reliability of FAS and JIFRC questionnaire. A value between .70 and .79 is considered 'fair', a value between .80 and .89 considered 'good', and a value .90 and above considered 'excellent' (Cicchetti,1994; Nunnally \& Bernstein, 1994; Michalopoulos et al., 2015). Table 1 Personal Characteristics of Samples $(n=170)$

\begin{tabular}{lcc}
\hline \multicolumn{1}{c}{ Variable } & Number & (\%) \\
\hline Age (years) & 34 & \\
$21-25$ & 47 & 19.4 \\
$>25-29$ & 35 & 27.6 \\
$>29-33$ & 12 & 20.0 \\
$>33-37$ & 13 & 6.9 \\
$>37-41$ & 29 & 7.4 \\
$>41$ & & 16.6 \\
Gender & 43 & \\
Male & 127 & 25.3 \\
Female & & 74.7 \\
Marital Status & & \\
\hline
\end{tabular}

\section{Ethical issue}

This study was reviewed and approved by the Ethical Commission of Health and Medical Research of Mulawarman University (Indonesia) Faculty of Medicine, which refers to The International Ethical Guidelines for Biomedical Research Involving Human Subjects and the international ethical guidelines for epidemiological studies from the Council for International Organisations of Medical Sciences (CIOMS 2016). Informed written consent was obtained from participants prior to their participation. The informed consent form stated the purpose of the study, data confidentiality terms and their voluntary right of participation in the study, as well as providing a guarantee that no participant would suffer any harm as a result of his or her participation in the study.

\section{Results}

\section{Samples characteristics}

The majority of respondents in this study were $>25-29$ years old $(27.6 \%)$, the majority of gender was female $(74.7 \%)$, the majority of marital status were married $(79.4 \%)$, education level is mostly Diploma III in Nursing, most of the working experience is more than 5 years $(50.6 \%)$ and employment status is mostly contract nurses $(72.4 \%)$ ( table 1).

\section{Results of the questionnaire validity test}


Iwan Muhamad Ramdan: Measuring Work Fatigue on Nurses: A Comparison between Indonesian Version

\begin{tabular}{lcc}
\hline Not Married & 35 & 20.0 \\
Married & 135 & 79.4 \\
Education Background & & \\
Strata 1 in Nursing & 38 & 21.7 \\
Diploma IV in Nursing & 14 & 8.2 \\
Diploma III in Nursing & 118 & 69.4 \\
Working Period & & \\
$1-5$ years & 84 & 49.4 \\
$>5$ years & 86 & 50.6 \\
Employee Status & & \\
Permanent & 47 & 26.9 \\
Contract & 123 & 72.4 \\
\hline
\end{tabular}

Table 2 Descriptive Characteristics And The Pearson Correlation (R) Of Each Data For Internal Consistency of Fatigue Assesment Scale (FAS) (n=170)

\begin{tabular}{lccccccc}
\hline \multicolumn{1}{c}{ Item } & Mean & SD & Variance & (r) & P Value & $\begin{array}{c}\text { Corrected } \\
\text { item/total } \\
\text { correlation }\end{array}$ & $\begin{array}{c}\text { Cronbach's } \\
\text { alpha if item } \\
\text { deleted }\end{array}$ \\
\hline $\begin{array}{l}\text { Item 1 (bothered by } \\
\text { fatigue) }\end{array}$ & 2.30 & 0.67 & 0.46 & 0.511 & 0.000 & 0.354 & 0.695 \\
$\begin{array}{l}\text { Item 2 (get tired very } \\
\text { quickly) }\end{array}$ & 2.18 & 0.63 & 0.40 & 0.511 & 0.000 & 0.366 & 0.694 \\
$\begin{array}{l}\text { Item 3 (don't do } \\
\text { much during the day) }\end{array}$ & 1.95 & 0.67 & 0.45 & 0.436 & 0.000 & 0.269 & 0.709 \\
$\begin{array}{l}\text { Item 4 (have enough } \\
\text { energy for everyday } \\
\text { life) }\end{array}$ & 2.78 & 0.64 & 0.42 & 0.113 & 1.144 & -0.065 & 0.755 \\
$\begin{array}{l}\text { Item 5 (physically } \\
\text { feel exhausted) }\end{array}$ & 2.30 & 0.72 & 0.52 & 0.607 & 0.000 & 0.458 & 0.677 \\
$\begin{array}{l}\text { Item 6 (problems to } \\
\text { start things) }\end{array}$ & 1.74 & 0.72 & 0.52 & 0.642 & 0.000 & 0.501 & 0.669 \\
$\begin{array}{l}\text { Item 7 (problems to } \\
\text { think clearly) }\end{array}$ & 1.75 & 0.61 & 0.37 & 0.608 & 0.000 & 0.485 & 0.676 \\
$\begin{array}{l}\text { Item 8 (no desire to } \\
\text { do anything) }\end{array}$ & 1.88 & 0.65 & 0.43 & 0.746 & 0.000 & 0.648 & 0.647 \\
$\begin{array}{l}\text { Item 9 (Mentally feel } \\
\text { exhausted) }\end{array}$ & 1.86 & 0.74 & 0.55 & 0.758 & 0.000 & 0.648 & 0.713 \\
$\begin{array}{l}\text { Item 10 (can } \\
\text { concentrate quite } \\
\text { well) } \\
\text { Total Score }\end{array}$ & 2.60 & 0.80 & 0.64 & 0.366 & 0.000 & 0.156 & 0.727 \\
\hline & 21.38 & 3.66 & 13.42 & 1 & & 1.000 & 0.834 \\
\hline
\end{tabular}

Table 3 Descriptive Characteristics And The Pearson Correlation (R) Of Each Data For Internal Consistency of Japan Industrial Fatigue Research Committee (J-IFRC) $(n=170)$

\begin{tabular}{cccccccc}
\hline Item & Mean & SD & Variance & (r) & P Value & $\begin{array}{c}\text { Corrected } \\
\text { item/total } \\
\text { correlation }\end{array}$ & $\begin{array}{c}\text { Cronbach's } \\
\text { alpha if item } \\
\text { deleted }\end{array}$ \\
\hline
\end{tabular}


Iwan Muhamad Ramdan: Measuring Work Fatigue on Nurses: A Comparison between Indonesian Version

\begin{tabular}{|c|c|c|c|c|c|c|c|}
\hline $\begin{array}{l}\text { Item } 1 \text { (The head } \\
\text { feels heavy) }\end{array}$ & 2.35 & 0.73 & 0.53 & 0.442 & 0.000 & 0.388 & 0.920 \\
\hline $\begin{array}{l}\text { Item } 2 \text { (Feel tired all } \\
\text { over the body) }\end{array}$ & 2.72 & 0.80 & 0.64 & 0.562 & 0.000 & 0.511 & 0.918 \\
\hline $\begin{array}{l}\text { Item } 3 \text { (Feet feels } \\
\text { heavy) }\end{array}$ & 2.54 & 0.93 & 0.86 & 0.479 & 0.000 & 0.412 & 0.921 \\
\hline $\begin{array}{l}\text { Item } 4 \text { (Frequency of } \\
\text { yawning) }\end{array}$ & 2.55 & 0.68 & 0.46 & 0.457 & 0.000 & 0.408 & 0.920 \\
\hline $\begin{array}{l}\text { Item } 5 \text { (Distracted } \\
\text { mind) }\end{array}$ & 2.05 & 0.59 & 0.35 & 0.621 & 0.000 & 0.587 & 0.917 \\
\hline Item 6 (Sleepy) & 2.44 & 0.65 & 0.42 & 0.496 & 0.000 & 0.451 & 0.919 \\
\hline $\begin{array}{l}\text { Item } 7 \text { (Eyes feel } \\
\text { heavy) }\end{array}$ & 2.28 & 0.78 & 0.61 & 0.525 & 0.000 & 0.472 & 0.919 \\
\hline $\begin{array}{l}\text { Item } 8 \text { (Rigid and } \\
\text { awkward to move ) }\end{array}$ & 1.65 & 0.58 & 0.33 & 0.492 & 0.000 & 0.452 & 0.919 \\
\hline $\begin{array}{l}\text { Item } 9 \text { (Feeling like } \\
\text { to lie down) }\end{array}$ & 1.74 & 0.56 & 0.32 & 0.538 & 0.000 & 0.501 & 0.919 \\
\hline $\begin{array}{l}\text { Item } 10 \text { (Feeling } \\
\text { difficult to think) }\end{array}$ & 2.54 & 0.77 & 0.60 & 0.612 & 0.000 & 0.566 & 0.918 \\
\hline $\begin{array}{l}\text { Item } 11 \text { (Tired of } \\
\text { talking) }\end{array}$ & 2.02 & 0.60 & 0.36 & 0.698 & 0.000 & 0.669 & 0.916 \\
\hline $\begin{array}{l}\text { Item } 12 \text { (Feeling } \\
\text { nervous) }\end{array}$ & 1.79 & 0.72 & 0.52 & 0.643 & 0.000 & 0.603 & 0.917 \\
\hline $\begin{array}{l}\text { Item } 13 \text { (It's hard to } \\
\text { concentrate) }\end{array}$ & 1.82 & 0.76 & 0.58 & 0.608 & 0.000 & 0.563 & 0.918 \\
\hline $\begin{array}{l}\text { Item } 14 \text { (It's hard to } \\
\text { focus) }\end{array}$ & 1.88 & 0.43 & 0.19 & 0.607 & 0.000 & 0.582 & 0.918 \\
\hline $\begin{array}{l}\text { Item } 15 \text { (Tend to } \\
\text { forget) }\end{array}$ & 1.87 & 0.51 & 0.26 & 0.615 & 0.000 & 0.585 & 0.918 \\
\hline $\begin{array}{l}\text { Item } 16 \text { (Lack of } \\
\text { trust) }\end{array}$ & 2.17 & 0.66 & 0.43 & 0.402 & 0.000 & 0.352 & 0.921 \\
\hline $\begin{array}{l}\text { Item } 17 \text { (Anxious } \\
\text { about something) }\end{array}$ & 1.89 & 0.69 & 0.47 & 0.476 & 0.000 & 0.427 & 0.920 \\
\hline $\begin{array}{l}\text { Item } 18 \text { (Cannot } \\
\text { control attitude) }\end{array}$ & 2.29 & 0.65 & 0.43 & 0.594 & 0.000 & 0.555 & 0.918 \\
\hline $\begin{array}{l}\text { Item } 19 \text { (Can not be } \\
\text { diligent in work) }\end{array}$ & 1.82 & 0.61 & 0.38 & 0.488 & 0.000 & 0.445 & 0.919 \\
\hline Item 20 (Headache) & 1.78 & 0.66 & 0.43 & 0.592 & 0.000 & 0.553 & 0.918 \\
\hline $\begin{array}{l}\text { Item } 21 \text { (Shoulder } \\
\text { feels stiff) }\end{array}$ & 2.29 & 0.65 & 0.43 & 0.583 & 0.000 & 0.543 & 0.918 \\
\hline $\begin{array}{l}\text { Item } 22 \text { (Feeling pain } \\
\text { in the back) }\end{array}$ & 2.25 & 0.72 & 0.53 & 0.609 & 0.000 & 0.566 & 0.918 \\
\hline $\begin{array}{l}\text { Item } 23 \text { (Shortness } \\
\text { of breath / difficult to } \\
\text { breathe) }\end{array}$ & 2.38 & 0.78 & 0.61 & 0.589 & 0.000 & 0.541 & 0.918 \\
\hline $\begin{array}{l}\text { Item } 24 \text { (Feeling } \\
\text { thirsty) }\end{array}$ & 1.72 & 0.71 & 0.51 & 0.583 & 0.000 & 0.539 & 0.918 \\
\hline Item 25 (Hoarseness) & 2.88 & 0.84 & 0.70 & 0.460 & 0.000 & 0.398 & 0.920 \\
\hline $\begin{array}{l}\text { Item } 26 \text { (Feeling } \\
\text { dizzy/dizzy) }\end{array}$ & 1.72 & 0.73 & 0.53 & 0.547 & 0.000 & 0.499 & 0.919 \\
\hline
\end{tabular}


Iwan Muhamad Ramdan: Measuring Work Fatigue on Nurses: A Comparison between Indonesian Version

\begin{tabular}{|c|c|c|c|c|c|c|c|}
\hline $\begin{array}{l}\text { Item } 27 \text { (Feeling dizzy } \\
\text { /dizzy) }\end{array}$ & 2.10 & 0.66 & 0.44 & 0.612 & 0.000 & 0.573 & 0.917 \\
\hline $\begin{array}{l}\text { Item } 28 \text { (The eyelids } \\
\text { feel heavy) }\end{array}$ & 1.72 & 0.69 & 0.47 & 0.536 & 0.000 & 0.491 & 0.919 \\
\hline $\begin{array}{l}\text { Item } 29 \text { (Trembling } \\
\text { in certain parts of the } \\
\text { body) }\end{array}$ & 1.58 & 0.58 & 0.34 & 0.654 & 0.000 & 0.623 & 0.917 \\
\hline $\begin{array}{l}\text { Item } 30 \quad \text { (Feeling } \\
\text { unwell) }\end{array}$ & 2.00 & 0.57 & 0.33 & 0.695 & 0.000 & 0.668 & 0.917 \\
\hline Total score & 62.81 & 11.37 & 129.32 & 1 & & 1.000 & 0.834 \\
\hline
\end{tabular}
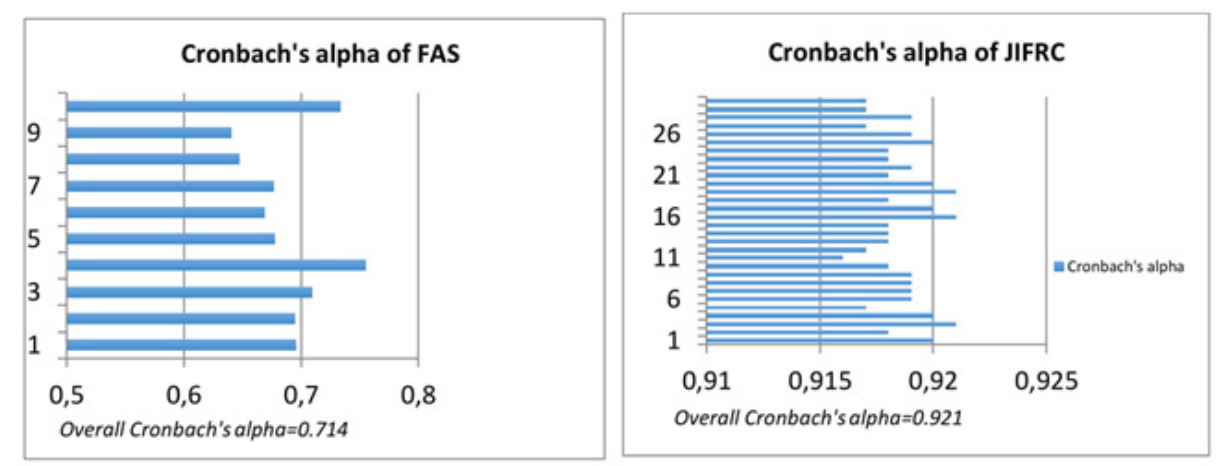

Figure 1 Reliability test result of FAS and JIFRC

The mean of the total FAS score was $21.38( \pm 3.66)$, its mean in this study the average nurse experienced work fatigue in the "low" category.The 4th item on "I have enough energy for everyday life" showed the highest score $(2.78, \pm 0.64)$, whereas the 6th item on "I have problems to start things" had the lowest score $(1.74 \pm 0.72)$. The largest variance was also observed in item 10th on "When I am doing something I can concentrate quite well" $(0.64, \pm 0.80)$ and smallest variance observed in item 7 th on "I have problems to think clearly" $(0.37, \pm$ $0.61)$. The smallest Pearson correlation value is 0.113 (item number 4 on "I have enough energy for everyday life"), and the largest Pearson correlation is 0.758 (item number 9 on "Mentally I feel exhausted"). Based on the previous criteria, it can be concluded that the item number 1, 2, 5, 6, 7, 8, 9 declared are "good" or in this study called as a valid because Pearson correlation (r) ranged between 0.5 and 0.7 . The item number 3 , 4 , and 10 declared are little/fair or in this study called as an invalid because Pearson correlation (r) ranged between $<0.25$ to 0.5 . (Table 2).
The mean of the total JIFRC score was $62.81( \pm 11.37)$, its mean in this study the average nurse experienced work fatigue in the "medium" category. The 25th item on "feeling thirsty" showed the highest score $(2.88, \pm 0.84)$, whereas the 29 th item on "trembling in certain parts of the body" had the lowest score $(1.58 \pm 0.58)$. The largest variance was also observed in item 3rd on "feet feel heavy" $(0.86, \pm 0.93)$ and smallest variance observed in item 14th on "it's hard to concentrate" $(0.19, \pm 0.43)$. The smallest Pearson correlation value is 0.40 (item number 16 on "tend to forget"), and the largest Pearson correlation is 0.698 (item number 11 on "feeling difficult to think"). Based on the previous criteria, it can be concluded that the item number $2,5,7,9,10,11,12,13,14$, $15,18,20,21,22,23,24,26,27,28,29,30$ declared are "good" or in this study called as a valid because Pearson correlation ( $\mathrm{r}$ ) ranged between 0.5 and 0.7 . The item number $1,3,4$, $6,8,16,17$ and 19 declared are fair or in this study called as an invalid because Pearson correlation (r) ranged between 0.25 to 0.5 . (Table 3). 
Results of the questionnaire reliability test

As shown in table 2 and figure 1 , If item question number 10 "When I am doing something I can concentrate quite well" is deleted this can increase Cronbach's alpha coefficient by 0.727 , If item question number 3 "I don't do much during the day" is deleted this can increase Cronbach's alpha coefficient by 0.709 and if item question number 4 "I have enough energy for everyday life" is deleted this can increase Cronbach's alpha coefficient by 0.755 . But in general, the combination of all 10 items of FAS has shown the fair reliability with Cronbach's alpha coefficient of 0,714 . This result generally shows the Indonesian version of FAS is reliable to measure work fatigue in nurses. To get the highest reliability index from this questionnaire, it is recommended to delete or correct question number 4 (have enough energy for everyday life).

Based on table 3 and figure 1, If item question number 1, 4 and 17 are deleted this can increase Cronbach's alpha coefficient by 0.920 , If item question number 3 and 16 are deleted this can increase Cronbach's alpha coefficient by 0.921 and if item question number 6, 8, 19 are deleted this can increase Cronbach's alpha coefficient by 0.919 . But in general, the combination of all 30 items of JIFRC has shown the excellent reliability with Cronbach's alpha coefficient of 0.921 . This result generally shows the Indonesian version of JIFRC is reliable to measure work fatigue in nurses.

Based on the comparison of Cronbach alpha values from FAS (0.714) and JIFRC $(0.921)$, it can be concluded that JIFRC is a more reliable work fatigue scale for measuring work fatigue in nurses, even though the Pearson correlation from both questionnaires is the same which ranges from $0.25-0.5$.

\section{Discussion}

To achieve the accuracy of the results of the study, the measuring instrument (questionnaire) used must be valid and reliable. Validity is to measure what is intended to be measured, explains how well the collected data covers the actual area of investigation and expresses the degree to which a measurement measures what it purports to measure. Reliability concerns the extent to which a measurement of a phenomenon provides stable and consist result, and also the degree to which the results obtained by a measurement and procedure can be replicated (Taherdoost, 2016; Bolarinwa, 2015).

The most appropriate method to assess the reliability of the questionnaire is Cronbach's alpha reliability coefficient, which has been frequently used to assess the internal consistency of Likert-type scales. If the items in a scale are equally weighted and independent, high correlation coefficients are expected to between each item and the total score (Aydin Özkan, Karaca, \& İster, 2017). Internal consistency describes the extent to which all the items in a test measure the same concept or construct and hence it is connected to the inter-relatedness of the items within the test. Internal consistency should be determined before a test can be employed for research or examination purposes to ensure validity (Tavakol \& Dennick, 2011).

Based on the comparison of the values of Cronbach alpha reliability test and Pearson correlation validity test, compared with the FAS, the JIFRC has proven the validity and reliability values higher, this instrument is more recommended for measuring work fatigue for nurses. Although overall the JIFRC questionnaire is good at measuring work fatigue for nurses, to further improve its validity and reliability it is recommended to improve grammar on items number $1,3,4$, $6,8,16$, and 19 , so that Pearson correlation coefficients are obtained more from 0.5 .

The results of this study are different from Fang, Katz, and Alberto, (2015) which proves that FAS is valid and reliable to measure work fatigue in construction in New England, research to measure work fatigue in nurses in Western North Carolina, and result of CanoCliment, et al. (2017) which proves FAS valid and reliable for measuring feelings of fatigue in postpartum women at Spanish. 
Iwan Muhamad Ramdan: Measuring Work Fatigue on Nurses: A Comparison between Indonesian Version

\section{Conclusion}

The study demonstrates that the Indonesian version of JIFRC fulfills the criteria of a reliable and valid assessment tool to rate the work fatigue among nurses, although there are eight question items that still need to be fixed. The high internal consistency and construct validity support the application of the JIFRC as an easy administered tool to assess work fatigue among nurses in Indonesian healthcare settings. The author is very grateful to all nurses who participated in this study, the hospital management who allowed this research and the enumerators. The author declares no conflict of interest.

\section{References}

Adiatmika, I. P. G. (2009). Total Ergonomic Approach in Decreasing Quality of Fatigue of Metal Crafters. Anima Indonesian Psychological Journal, 25(1), 71-78.

Akerstedt, T., \& Gillberg, M. (1990). Subjective and objective sleepiness in the active individual. Int $J$ Neurosci, 52(1-2), 29-37.

Aydin Özkan, S., Karaca, T., \& İster, E. D. (2017). Validity and reliability of the "perceptions of restraint use questionnaire" for use in Turkey. Turk Geriatri Dergisi, 20(1), 30-37. Retrieved from http://www. embase.com/search/results?subaction=viewr ecord\&from=export\&id=L615141041.

Bao, S., \& Taliaferro, D. (2015). Compassion Fatigue and Psychological Capital in Nurses Working in Acute Care Settings. International Journal for Human Caring, 19(2), 35.

Barker, L., \& Nussbaum, M. (2011). Fatigue, performance and the work environment: a survey of registered nurses. J Adv Nurs, 67(6), 1370-1380.

Bjorvatn, B., Dale, S., Hogstad-Erikstein, R., Fiske, E., \& Pallesen, S. (2012). Self-reported sleep and health among Norwegian hospital nurses in intensive care units. Nurs Crit Care, 17(4), 180-188.

Blouin, A., Smith-Miller, C., Harden, J., \& Li, Y. (2016). Caregiver Fatigue: Implications for Patient and Staff Safety, Part 1. J Nurs Adm, 46(6), 329-335.

Bolarinwa, O. (2015). Principles and methods of validity and reliability testing of questionnaires used in social and health science researches. Nigerian Postgraduate Medical Journal, 22(4), 195-201. https://doi. org/10.4103/1117-1936.173959.

Cano-Climent, A., Oliver-Roig, A., CabreroGarcía, J., de Vries, J., \& Richart-Martínez, M. (2017). The Spanish version of the Fatigue Assessment Scale: reliability and validity assessment in postpartum women. PeerJ, 5, e3832. https://doi.org/10.7717/peerj.3832.

Carney, L. M. (2013). The hidden shift: how do night shift nurses learn to adapt to circadian disruption? J Nurses Prof Dev., 29(6), 316-320.

Cicchetti, D. V. (1994). Guidelines, Criteria, and Rules of Thumb for Evaluating Normed and Standardized Assessment Instruments in Psychology. Psychological Assessment, 6(4), 284-290. https://doi.org/10.1037/10403590.6.4.284.

De Vries, J., Michielsen, H., \& Van Heck, G. (2003). Assessment of fatigue among working people: a comparison of six questionnaires. Occup Environmen Med, 60(Suppl 1), i10-i15. https://doi.org/10.1016/00163287(94)90002-7.

De Vries, J., Van der Steeg, A. F., \& Roukema, J. A. (2010). Psychometric properties of the Fatigue Assessment Scale (FAS) in women with breast problems. International Journal of Clinical and Health Psychology, 10(1), 125-139.

Dittner, A., Wessely, S., \& Brown, R. (2004). The assessment of fatigue - A practical guide for clinicians and researchers. Jurnal of 
Iwan Muhamad Ramdan: Measuring Work Fatigue on Nurses: A Comparison between Indonesian Version

Psychosomatic Research, 56(2), 157-170.

Drake, D., \& Steege, L. (2016). Interpretation of Hospital Nurse Fatigue Using Latent Profile Analysis. ANS Adv Nurs Sci, 39(3), E1-E16.

Fang, D., Katz, J. N., \& Alberto, J. (2015). Development and Validation of a Fatigue Assessment Scale for U.S. Construction Workers. Am J Ind Med, 58(2), 220228. https://doi.org/10.1002/ajim.22411. Development.

Graves, K., \& Simmons, D. (2009). Reexamining fatigue: implications for nursing practice. Crit Care Nurs Q., 32(2), $112-115$.

Heale, R., \& Twycross, A. (2015). Validity and reliability in quantitative studies. Evidence Based Nursing, 18(3), 66-67. https://doi. org/10.1136/eb-2015-102129.

Hendriks, C., Drent, M., Elfferich, M., \& Vries, J. De. (2018). The Fatigue Assessment Scale : quality and availability in sarcoidosis and other diseases. Pulmonary Medicine, 24, 1-9. https://doi.org/10.1097/ MCP.0000000000000496.

Kline, P. (2000). The Handbook of Psychological Testing (Second). London and New York: Routledge.

Konisi, Y., Horiguchi, S., Miyama, Y., \& Kawai, T. (1991). A questionnaire study on fatigue symptoms of municipal personnel. Osaka City Med, 37(2), 157-162.

Korompeli, A., Chara, T., Chrysoula, L., \& Sourtzi, P. (2013). Sleep disturbance in nursing personnel working shifts. Nurs Forum, 48(1), 45-53.

Michalopoulos, L. T. M., Murray, L. K., Kane, J. C., Van Wyk, S. S., Chomba, E., Cohen, J., ... Bolton, P. A. (2015). Testing the validity and reliability of the Shame Questionnaire among sexually abused girls in Zambia. PLoS ONE, 10(4), 1-17. https:// doi.org/10.1371/journal.pone.0123820.
Michielsen, H. J., De Vries, J., Van Heck, G. L., Van de Vijver, F. J. R., \& Sijtsma, K. (2004). Examination of the Dimensionality of Fatigue: The Construction of the Fatigue Assessment Scale (FAS). European Journal of Psychological Assessment, 20(1), 39-48. https://doi.org/10.1027/1015-5759.20.1.39.

Nunnally, J. C., \& Bernstein, I. H. (1994). Psychometric Theory (3rd ed.). USA: McGraw-Hill, Inc.

Portney, L., \& Watkins, M. (2009). Foundations of clinical research: applications to practice Pearson education. New Jersey: Upper Saddle River.

Rahman, A. H., Mimin, Abdul, K., \& NAing, L. (2017). Psychosocial factors, musculoskeletal disorders and work-related fatigue amongst nurses in Brunei: structural equation model approach. Int Emerg Nurs, $34,17-22$.

Saito, K. (1999). Measurement of fatigue in industries. Ind Health, 37(2), 134-142. https://doi.org/10.2486/indhealth.37.134.

Samaha, E., Lal, S., Samaha, N., \& Wyndham, J. (2007). Psychological, lifestyle and coping contributors to chronic fatigue in shift-worker nurses. J Adv Nurs, 59(3), 221-232.

Scott, L. D., Engoren, C. A., \& Engoren, M. C. (2014). Association of Sleep and Fatigue With Decision Regret Among Critical Care Nurses. American Journal Od Critical Care, 23(1), 13-23.

Sibsambhu, K., Mayank, B., \& Aurobinda, R. (2010). EEG signal analysis for the assessment and quantification of driver's fatigue. Transportation Research Part F, 13, 297-306.

Steege, L., Pinekenstein, B., Rainbow, J., \& Knudsen,A. (2017). Addressing Occupational Fatigue in Nurses: Current State of Fatigue Risk Management in Hospitals, Part 1. J Nurs Adm, 47(9), 426-433.

Sudo, N., \& Ohtsuka, R. (2002). Fatigue Complaints Among Female Shift Workers 
Iwan Muhamad Ramdan: Measuring Work Fatigue on Nurses: A Comparison between Indonesian Version

in a Computer Factory of Japan. J. Human Ergol, 31, 41-51.

Sunarno, S. D. A. M., Ramdhan, D. H., Efendi, H., \& Amalaili, P. (n.d.). Study of Shift Work, Quantity and Quality of Sleep with the Occurrence of Fatigue at Universitas Indonesia Security, 2017. In Int. Conference of Occupational Health and Safety (ICOHS-2017) (Vol. 2018, pp. 709717). https://doi.org/10.18502/kls.v4i5.2601.

Susihono, W., Parwata, Y., \& Sandi, N. (2016). Ergonomics participatory decrease fatigue, musculoskeletal disorders, and increase the comfort in assembling the net of tonis game. Bali Med J, 5(1), 179-184. https://doi.org/10.15562/bmj.v5i1.341.

Taherdoost, H. (2016). Validity and Reliability of the Research Instrument; How to Test the Validation of a Questionnaire / Survey in a Research. International Journal of Academic Research InManagement (IJARM), 5(3), 28-
36.

Tarwaka. (2010). Ergonomic Industry; Ergonomic Basic Knowledge and the Application in Working Place. (1st ed.). Solo: Harapan Press.

Tavakol, M., \& Dennick, R. (2011). Making sense of Cronbach's alpha. International Journal of Medical Education, 2, 53-55. https://doi.org/10.5116/ijme.4dfb.8dfd.

Thiffault, P., \& Bergeron, J. (2003). Fatigue and individual differences in monotonous simulated driving. Personality and Individual Differences, 34(1), 159-176. https://doi. org/10.1016/S0191-8869(02)00119-8.

Zuraida, R., \& Chie, H. H. (2014). Pengujian Skala Pengukuran Kelelahan Kerja (SPK) Pada Responden di Indonesia. (Testing the Work Fatigue Measurement Scale (SPK) of Respondents in Indonesia). ComTech, 5(2), 1012-1020. 